\title{
USE OF BOTANICAL INSECTICIDES AS AN ALTERNATIVE FOR THE MANAGEMENT OF THE MEXICAN BEAN WEEVIL ${ }^{1}$
}

\author{
KAREN FERREIRA DA SILVA ${ }^{2}$, EDSON LUIZ LOPES BALDIN ${ }^{3}$, LUIZ EDUARDO DA ROCHA PANNUTI ${ }^{3 *}$
}

\begin{abstract}
This study aimed to evaluate the insecticidal activity of eight botanical species in the behavior and biological development of Zabrotes subfasciatus (Coleoptera: Chrysomelidae: Bruchinae) under laboratory conditions. The botanical species were applied on bean grains (Phaseolus vulgaris Linnaeus) directly as powder or indirectly within TNT bags. Three laboratory assays were performed. First, a repellent activity test was performed by exposing twenty couples of $Z$. subfasciatus adults in a choice-test arena. Second, a mortality test was performed for seven days after infestation. Finally, the oviposition and emergency rates of adults (\%) and the development from egg to adult (in days) were evaluated in seven couples (males and females) for seven days inside of a vial containing $0.3 \mathrm{~g}$ of the powder from each botanical species and $10 \mathrm{~g}$ of bean grains $(3 \%$ $\left.\mathrm{w} \cdot \mathrm{w}^{-1}\right)$. The study was conducted in a completely randomized design, and the treatments were arranged as a factorial design $(2 \times 9)$ with two factors (factor $1=$ powder and TNT bag application forms and factor $2=$ eight botanical species and control) with eight replications. The powder application form was more efficient in controlling Z. subfasciatus. Azadirachta indica (powder application), Ruta graveolens (powder application), and Piper aduncum (TNT bag) reduced the infestation of adults. The species A. inidica, Piper tuberculatum, Trichilia catigua, Pfaffia glomerata, R. graveolens, and Mentha pulegium inhibited the oviposition of the insects regardless of the formulation applied. $R$. graveolens (powder application) caused $100 \%$ of mortality. The powder application of $R$. graveolens and M. pulegium reduced egg viability and insect emergence; therefore, they are very promising alternatives to control Z. subfasciatus in stored grains.
\end{abstract}

Keywords: Bruchinae. Chrysomelidae. Zabrotes subfasciatus.

\section{INSETICIDAS VEGETAIS COMO ALTERNATIVA PARA O MANEJO DO CARUNCHO-DO- FEIJÃO}

RESUMO - O objetivo do trabalho foi avaliar o efeito de pós de oito espécies botânicas, misturados aos grãos de feijão, Phaseolus vulgaris (Fabaceae), ou em sachês, sobre os aspectos comportamentais e de desenvolvimento biológico de Zabrotes subfasciatus (Coleoptera: Chrysomelidae: Bruchinae) em laboratório. Três ensaios foram realizados. Primeiro, a repelência de adultos de $Z$. subfasciatus pelas espécies vegetais foi avaliada com 20 casais em teste com chance de escolha. Segundo, a mortalidade de adultos foi avaliada, diariamente, até o sétimo dia após a infestação. Terceiro, sete casais foram mantidos por sete dias em recipientes contendo $0,3 \mathrm{~g}$ de pó de cada espécie vegetal e $10 \mathrm{~g}$ de grãos de feijão $\left(3 \% \mathrm{p} \cdot \mathrm{p}^{-1}\right)$ para avaliação dos parâmetros oviposição, emergência de adultos (\%) e período de desenvolvimento ovo-adulto (dias) de $Z$. subfasciatus. Os ensaios seguiram arranjo fatorial $2 \times 9$ (fator $1=$ formas de aplicação pó e sachê; fator $2=$ oito espécies vegetais e testemunha) em delineamento inteiramente casualizado com oito repetições. A forma de pó foi mais eficiente no controle de Z. subfasciatus. As espécies Azadirachta indica (na forma de pó), Ruta graveolens (na forma de pó) e Piper aduncum (na forma de sachê) reduziram a infestação por adultos do inseto. A. indica, Piper tuberculatum, Trichilia catigua, Pfaffia glomerata, R. graveolens e Mentha pulegium, independente da forma de aplicação utilizada, inibiram a oviposição do inseto. $R$. graveolens (na forma de pó) controlou $100 \%$ de adultos. Pós das espécies $R$. graveolens e M. pulegium reduziram a viabilidade de ovos e emergência do inseto, apresentando alto potencial no controle alternativo de Z. subfasciatus em feijão armazenado.

Palavras-chave: Bruchinae. Chrysomelidae. Zabrotes subfasciatus.

\footnotetext{
${ }^{*}$ Corresponding author

${ }^{1}$ Received for publication in $03 / 17 / 2015$; accepted in 01/28/2016

${ }^{2}$ Department of Entomology, University of Nebraska, Lincoln, NE, USA; kfdsilva@gmail.com.

${ }^{3}$ Department of Crop Protection, Universidade Estadual Paulista "Júlio de Mesquita Filho", Botucatu, SP, Brazil; elbaldin@fca.unesp.br, luizpannutixl@yahoo.com.br.
} 


\section{INTRODUCTION}

The common bean Phaseolus vulgaris Linnaeus (Fabaceae) is an important crop in the tropics, mainly in Africa and Latin America (HILLOCKS et al., 2006; OJWANG' et al., 2011), as it is a rich source of protein in the dietery of over 500 million of people worldwide (BROUGHTON et al. 2003; CORTÉS et al., 2012). The grains of this Fabaceae are usually stored for several months after harvesting or even for longer periods of time when the commodity prices are lower than desired. The grains can be attacked by different pest species during the storage process, compromising the quality and value of the commodity (SINGH; VAN EMDEN, 1979; WONG-CORRAL; CASTAÑÉ; RIUDAVETS, 2013).

Bean weevils, such as Zabrotes subfasciatus (Bohemann, 1833) (Coleoptera: Chrysomelidae: Bruchinae), are important pests of stored grains and usually cause damage inside grain storage bins (CARDONA et al., 1989; WONG-CORRAL; CASTAÑÉ; RIUDAVETS, 2013). The damage in grains by $Z$. Subfasciatus is caused by the penetration and feeding of the larvae inside of the grains, resulting in reduction of weight, nutrition value and germination rates. Moreover, the infestation in grains by Z. Subfasciatus can affect the appearance of the grains once the presence of dead insects, feces and holes due to the emergence of the adults as well as the smell and taste alteration are importante factors that lead to the product depreciation (PAUL et al., 2009; WONG-CORRAL; CASTAÑÉ; RIUDAVETS, 2013).

Chemical control via the application of phosphine gas, organophosphates and pyrethroids is the most efficient way to control pests in stored grains (GUSMÃO et al., 2013). However, the options of insecticides available are limited due to restricted laws applied for a safe application (MOHAN;

PRETHEEP-KUMAR; BALASUBRAMANIAN, 2010). Problems such as residue accumulation in the grains, selection for resistance, and other side effects increase the need for alterantive methods in order to reduce the application of these products (KEMABONTA; ODEBIYI, 2005; GUSMÃO et al., 2013).

The application of products extracted from plants (botanical insecticides) is a promising ecological alternative to control agricultural pests in the field and in grain warehouses (SCOTT et al., 2008; GUSMÃO et al., 2013). Derivatives of plants with insecticide properties to control Z. subfasciatus are applied in countries such as Africa, Latin America, and Asia in the form of extract, powder or oil. These products have insecticide properties, including oviposition inhibition, mortality, reduction of larval development, and repellency (WEAVER et al., 1994; COSTA et al., 2014). Moreover, botanical products have low toxicicity to mammals, low residual rates in the environment, and their molecule complexicity delays the development of resistance in insect populations (MIRESMAILLI; BRADBURY; ISMAN, 2006).

The objective of this study was to evaluate the effect of the powder of different botanical species in two application forms on the behavior and development aspects of $Z$. subfasciatus in bean grains.

\section{MATERIAL AND METHODS}

The study was conducted in 2011 and 2012 under laboratory conditions inside growth chambers maintained at temperatures of $25 \pm 2{ }^{\circ} \mathrm{C}$, with relative humidity at $70 \pm 10 \%$. The chambers were maintained at a photoperiod of 12: 12 (light : dark) h.

\section{Rearing of $Z$. subfasciatus}

Z. subfasciatus was obtained from a stock colony reared in a growth chamber $\left(\mathrm{T}=25 \pm 2^{\circ} \mathrm{C}\right.$; $\mathrm{RH}=70 \pm 5 \%$ and photoperiod of $12: 12$ (L:D). Clear glass containers $(1 \mathrm{~L})$, sealed with a screw- on lid containing a circular hole covered by a 35-mesh screen, were used. Each glass container received 0.3 $\mathrm{kg}$ of bean grains of $P$. vulgaris (Bolinha and IACCarioca varieties) and approximately 300 of nonmated adults of $Z$. subfasciatus. Thirty days after the infestation, the grains were sifted and the emerged adults were transferred to new containers with the same amount of grains. The beans from the containers were sifted, and the emerged adults were separated in different containers in order to obtain insects at the same age. The beans used for rearing and for the bioassays were previously stored in a cold chamber at $2-3{ }^{\circ} \mathrm{C}$ for five days. Subsequently, the beans were added to plastic containers and stored in a growth chamber $\left[\mathrm{T}=25 \pm 2^{\circ} \mathrm{C} ; \mathrm{RH}=70 \pm 5 \%\right.$ and photoperiod of 12:12 (L:D)] for ten days until reaching the hygroscopic equilibrium (CASTRO et al., 2013).

\section{Collection of biological material and preparation of application form}

Eight botanical species were used: almonds of Azadirachta indica (A.) (Meliaceae), leaves of Mentha pulegium (L.) (Lamiaceae), almonds of Pfaffia glomerata (Spreng.) (Pedersen.) (Amaranthaceae), leaves of Piper aduncum (L.) (Piperaceae), leaves of Piper tuberculatum (Jacq.) (Piperaceae), leaves of de Ruta graveolens (L.) (Rutaceae), leaves of Trichilia catigua (A. Juss.) (Meliaceae) and leaves of Trichilia pallida (Swartz.) (Meliaceae).

A. indica e $R$. graveolens were acquired from the market in Ribeirão Preto City, São Paulo State. 
M. pulegium was acquired in Patrocínio City, Minas Gerais State and its voucher specimen (61.681) is deposited in the Uberlandense Herbarium (HUFU). $P$. glomerata was collected in Campinas City, São Paulo State and its voucher specimen (CPQBA 0238) is deposited in the UNICAMP Herbarium (CPQBA 0238). P. aduncum was collected in São Paulo City, São Paulo State and its voucher specimen (K-057) is deposited in the São Paulo University Herbarium (SPF). T. catigua was collected in Curitiba City, Paraná State and its voucher specimen (65.901) is deposited in the Municipal Botanical Museum Herbarium of Curitiba. T. pallida was collected in Piracicaba City, São Paulo State and its voucher specimen (28.298) is deposited in the Irina Delanova Gemtchujnikov Herbarium (BOTU).

The botanical species and their structures were collected based on their history of efficiency against some insect species as well as on scientific interest and collection availability.

The botanical structures of each species were collected between March and September of 2011 and dried by air circulation at $40{ }^{\circ} \mathrm{C}$ for $48 \mathrm{~h}$. The dried material was ground in a gringing wheel to obtain the powder form (BALDIN et al., 2009). The powders extracted from each botanical structure were stored in plastic containers and hermetically sealed (BALDIN et al., 2007).

The botanical derivatives were tested in two forms: first, they were mixed within the grains, and second they were added within TNT bags (sachet format) and mixed with the grains. The concentration of $3 \% \quad\left(p \cdot p^{-1}\right)$ was used for the two forms of application $(0,3 \mathrm{~g}$ of powder mixed to $0,3 \mathrm{~g}$ of powder within the sachet with $10 \mathrm{~g}$ of bean grains). The bags were designed by using nonwoven fabric (TNT) to allow the volatilization of possible bioactive compounds.

\section{Repellency assay}

The repellency of adults of $Z$. subfasciatus by using the refered botanical species was evaluated within an arena designed by four Petri dishes $(6,5 \mathrm{~cm}$ diameter x 2,0 cm lenght). Another Petri dish with the same measurements was placed in the middle and symetrically interlinked diagonally to the other Petri dishes by plastic tubes (MAZZONETTO; VENDRAMIM, 2003). A total amount of $10 \mathrm{~g}$ of beans from the variety Pérola were mixed into the powder or sachet at the concentration of $3 \%$, and the control (i.e., only bean grains without any treatment) were added, respectively, in the two simetrically opposite Petri dishes. Twenty recently emmerged mates (less than 24h after emergency) of the bean weevil were added into the centrally located Petri dish. The number of insects per Petri dish were counted at 12, 24, and 48 hours after infestation. There were nine treatments total (eight botanical species and one control) in two application forms (powder and sachet). The assays were repeated eight times, and the results were analyzed as a completely randomized design (CRD).

The treatments were also compared among themselves using the repellency index (RI) calculated by the formula $\mathrm{RI}=2 \mathrm{P} /(\mathrm{P}+\mathrm{T})$, where $\mathrm{P}$ is the percentage of insects within the treated bean grains, and $\mathrm{T}$ is the percentage of insects in the control group. The index values vary between zero and two; the RI = 1 indicates the neutral compound, $\mathrm{RI}>1$ indicates the attractant compound, and $\mathrm{RI}<1$ indicates the repellent compound (LIN; KOGAN; FISCHER, 1990). The standard deviation of each treatment was added/subtracted to the index 1,0 (neutral indicator). As a conclusion, the repellency or atractiveness of each treatment was considered only when the RI is applied outside of the 1,0 $\pm \mathrm{SD}$ range (MAZZONETTO; VENDRAMIM, 2003).

\section{Mortality assay}

The mortality of adults of $Z$. subfasciatus was evaluated by adding six recently emerged mates in plastic containers $(4,0 \mathrm{~cm}$ of diameter $\mathrm{x} 5,0 \mathrm{~cm}$ of length) with $0.30 \mathrm{~g}$ of powder or one sachet mixed to $10 \mathrm{~g}$ of bean grains $\left(3 \%\right.$ p. $\left.\mathrm{p}^{-1}\right)$. The assay results were analyzed by the same factorial design described in the repellency test and by a completely randomized design with eight repetitions for each tretament. The dead insects were counted and removed from the plastic containers daily for seven days from the date of the infestation (MAZZONETTO; VENDRAMIM, 2003).

\section{Biological parameter assay}

The oviposition, egg viability, adult emergence, and the period of egg-adult development were evaluated based on a no-choice test, followed by the same methodology and experimental design used in the mortality assays. The insects were removed seven days after infestation (DAI). After 20 DAI, the number of eggs per container was counted to obtain the percentage of viable eggs. The oviposition preference index was also calculated (BALDIN et al., 2008) using the formula OPI $=[(\mathrm{T}-$ $\mathrm{P} / \mathrm{T}+\mathrm{P})] \mathrm{x} 100$, where $\mathrm{T}$ is the total number of eggs counted in the treated bean grains, and $\mathrm{P}$ is the number of eggs present in the control group (without botanical extracts). This index varies from +100 (very stimulant) to -100 (totally deterrent), where a value zero indicates neutrality. Classification was made by comparing the average of number of eggs in the treatment condition with the control and by considering the standard error of the mean for statistically significant results. The OPI index were calculated for nine treatments (eight botanical species and one control) and in two application forms (powder and sachet). Starting at $25 \mathrm{DAI}$, the assays were evaluated daily in order to determine the 
number of emerged adults and the period of eggadult development of Z. subfasciatus.

\section{Statistical analysis}

The normality and homogeneity of the data was verified by using Kolmogorov-Smirnov and Levene tests (Winer et al., 1991), respectively. The means were compared by Scott-Knott test $(\mathrm{p} \leq 0.05)$. The statistical program used was Sisvar, version 5.3
(Lavras, Minas Gerais state, Brazil) (Sisvar, 2010).

\section{RESULTS AND DISCUSSION}

\section{Repellency assay}

The powder treatments with extracts of $A$. indica $(0.88)$ e $R$. graveolens $(0.67)$ were considered repellent to $Z$. subfasciatus (Figure 1).

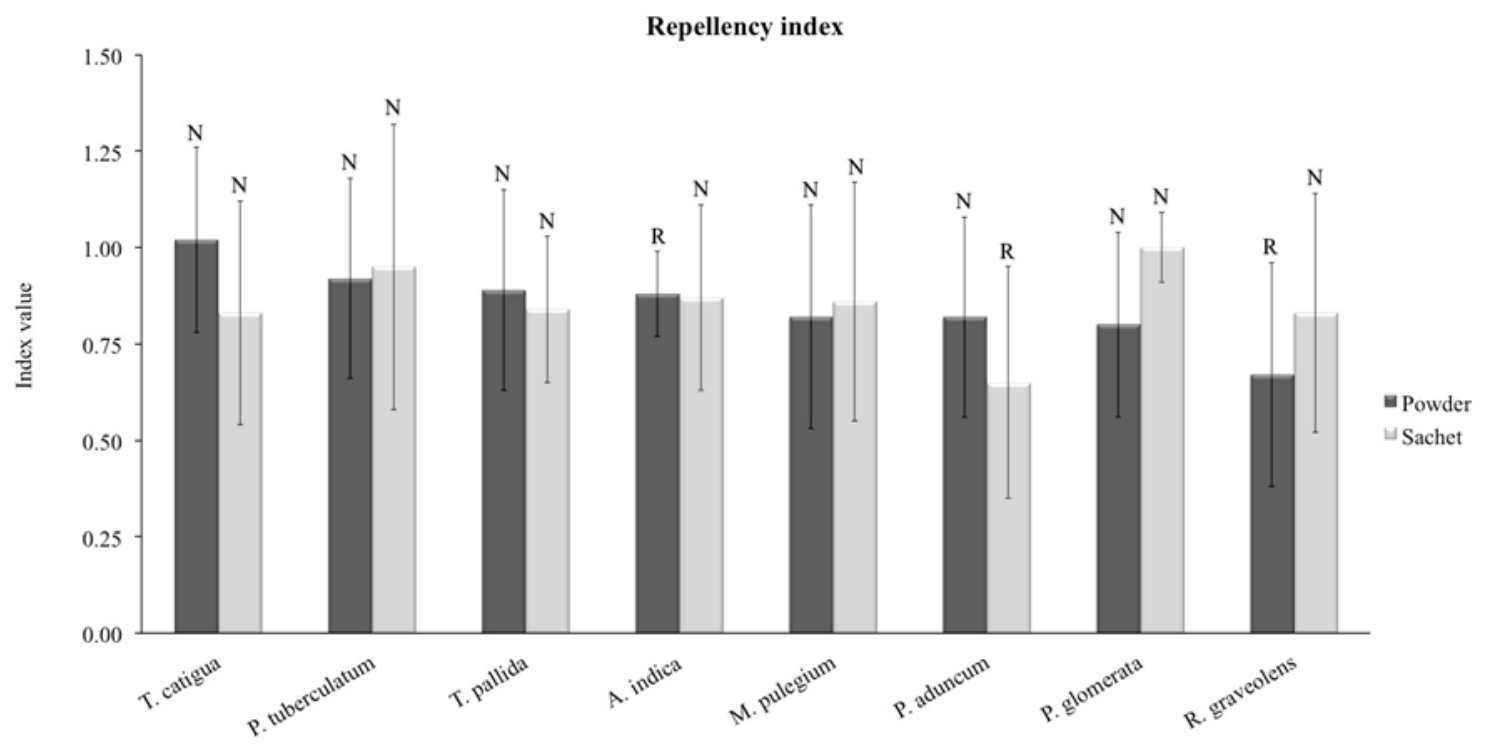

$\mathrm{N}=$ Neutral; $\mathrm{R}=$ Repellent.

$R I=2 P /(P+T)$, where $P$ is the percentage of insects in the containers with terated bean grains, and $T$ is the percentage of insects in the control containers. The index varies between zero to two. RI $=1$ indicates neutral treatment, RI $>1$ indicates atractant treatment, and $\mathrm{RI}<1$ indicates a repellent treatment.

Figure1. Repellency index and classification of the botanical species to adults of $Z$. subfasciatus in treated bean grains by powder application form and sachet at $25 \pm 2{ }^{\circ} \mathrm{C}$, relative humidity of $70 \pm 10 \%$, and photoperiod of 12:12 (light:dark) h.

Regarding the sachet form of application, $A$. indica $\mathrm{e} R$. graveolens did not reduce the atractiveness of the insect as observed in the powder application form, and they were classified as neutral (Figure 1). Mazzonetto and Vendramim (2003) observed similar results when using the powder form of $R$. graveolens mixed to the bean grains, which caused a repellent effect toward the adults of Acanthoscelides obtectus (Say) (Coleoptera: Bruchidae). However, the same authors did not verify the repellency to the species $A$. indica, which contrasts with the data obtained in this study. It is important to highlight that the powder from a determined botanical species can affect the bean weevil species differently (MAZZONETTO; VENDRAMIM, 2003; PANNUTI; MARCHI; BALDIN, 2012).

$A$. indica and $R$. graveolens did not reduce the attractivity of the insect when applied as sachet as it was observed when applying as powder treatment therefore, these species are classified as neutral
(Figure 1). Mazzonetto and Vendramim (2003) observed similar results when applying $R$. graveolens powder to the bean grains, which caused a repellent effect over adults of Acanthoscelides obtectus. However, differring from this study, the same authors did not verifiy the repellent effect of $A$. Indica. It is important to emphasize that the powder form of one determined botanical species can affect the weevil species differenltly (MAZZONETTO; VENDRAMIM， 2003; PANNUTI; MARCHI; BALDIN, 2012). The repellent activity observed in $R$. graveolens to A. obtectus and Z. subfasciatus was interesting, since these species generally are common hosts of bean grains, mostly under storage conditions. Thus, the use of this botanical product would promote the management of both species. The bioactivity of plants is attributed to the several secondary compounds, mostly the volatile compounds that are present with their own diversity of structures (ISMAN, 2006; MORGAN, 2009). The repellent effect of these botanical species to the 
insect is probably caused by the content of these compounds in the plant structures used in the current study. These insecticide properties are attributed to several chemical compounds, specially to the active compound azadirachtin tetranotriterpenóide (MORGAN, 2009). With regard to $R$. graveolens, its aerial structure has more than 120 compounds described and related to different classes, such as acridone alkaloids, coumarin, essential oils, and flavonoids (OLIVA et al., 2003). These compounds can present deterrent and insecticide properties over several insect species (GUARRERA, 1999; ROJHT; KOSIR; TRDAN, 2012).

$P$. aduncum (0.65) was the only species to transform the bean grains to be repellent to the weevil in the sachet application form (Figure 1). It is well known that the Piperaceae family generally possesses promising secondary compounds with insecticide activity. The effect of these phytochemicals is related mostly to the concentration of piperamides (e.g., piperine) and can show uncounted modes of action, including repellent, contact, and antifeeding effects (SCOTT et al., 2008). This suggests the effect of $P$. aduncum is due to the existence of these volatile compounds on its tested structures. Even though a promising result was demonstrated by using sachet, it was expected that the powder form could cause a similar repellent effect to the insect; however this was not observed in this study.

\section{Mortality assay}

In the mortality evaluation, there was a significant interaction between the species $R$. graveolens, A. indica, T. Pallida, and M. pullegium and the evaluated application forms. In general, the powder application form was more efficient to control Z. subfasciatus than the sachet application form. The application of $R$. graveolens, in powder form mixed with the bean grains, presented higher toxicity over the $Z$. subfasciatus adults, causing $100 \%$ mortality at seven DAI (Table 1). Rojht, Kosir and Trdan (2012) reported the existence of several secondary compounds with insecticide properties in ethanolic extracts of $R$. graveolens, such as rutin, xantoxina, cavacrol, coumarin, bergapten, and others. These compounds generally exhibit strong bioactivity against several species of insects (MOREIRA et al., 2007; BARBOZA et al. 2010; MAGALHAES et al. 2010). In a study conducted by Rojht, Kosir and Trdan (2012), the application of ethanolic extract of $R$. graveolens over the bean grains also resulted in $100 \%$ mortality of $A$. obtectus adults after the seventh day, which is similar to what was verified with $Z$. subfasciatus adults in the present study. This also suggests the presence of these substances when the plant is applied in powder form.

Table 1. Mean values $( \pm \mathrm{SE})$ to the mortality of adults of $Z$. subfasciatus in bean grains treated with powder and sachet of different botanical species at $25 \pm 2{ }^{\circ} \mathrm{C}$, relative humidity of $70 \pm 10 \%$, and photoperiod of 12:12 (light:dark) h.

\begin{tabular}{lcc}
\hline & \multicolumn{2}{c}{$\begin{array}{c}\text { Mortality(\%) } \\
\text { Application form }\end{array}$} \\
Botanical species & Powder & $14.00 \pm 5.03 \mathrm{aB}$ \\
\hline R. graveolens & $100.00 \pm 0.00 \mathrm{aA}$ & $5.00 \pm 2.34 \mathrm{bB}$ \\
A. indica & $24.00 \pm 5.82 \mathrm{bA}$ & $6.04 \pm 2.13 \mathrm{bB}$ \\
Control & $19.10 \pm 3.51 \mathrm{bA}$ & $16.00 \pm 4.02 \mathrm{aA}$ \\
$P$. glomerata & $19.00 \pm 2.67 \mathrm{bA}$ & $6.00 \pm 2.13 \mathrm{bB}$ \\
T. pallida & $18.00 \pm 4.26 \mathrm{bA}$ & $5.00 \pm 1.69 \mathrm{bB}$ \\
M. pulegium & $17.00 \pm 4.53 \mathrm{bA}$ & $7.00 \pm 2.16 \mathrm{bA}$ \\
T. catigua & $14.25 \pm 4.20 \mathrm{bA}$ & $6.00 \pm 1.66 \mathrm{bA}$ \\
$P$. aduncum & $6.00 \pm 3.11 \mathrm{cA}$ & $5.00 \pm 2.20 \mathrm{bA}$ \\
$P$. tuberculatum & $3.00 \pm 1.59 \mathrm{cA}$ & \\
& $P$ probability & \\
Botanical species (S) & $<0.001$ & \\
Application form (F) & $<0.001$ & \\
E x F & $<0.001$ & \\
\hline
\end{tabular}

${ }^{1}$ Means followed by same lowercase letter, in the columns, or uppercase in the row, did not significantly differ by Skott-Knott test $(\mathrm{p} \geq 0.05)$. 
In the sachet application form, P. glomerata and $R$. graveolens presented similar percentages of mortality, lower than $20 \%$, which is considered lower than the powder form (Table 1). Probably the lack of contact of the powder to the grains and insects reduced the bioactivity of the botanical species, suggesting that the fumigant effect of the volatile substances is limited.

\section{Biological parameters assay}

There was significant interaction between the species $R$. graveolens and the application forms in relation to the oviposition of $Z$. subfasciatus. The grains mixed to the powder of these plants were less oviposited by $Z$. subfasciatus, with the exception of $P$. aduncum (133.50) that was not significantly different from the control. In the sachet form of application, only the $M$. pulegium (67.88) treatment presented the lower oviposition of the weevil in relation to the control (Table 2).

Table 2. Mean values $( \pm \mathrm{SE}$ ) to the total number and eggs viability of $Z$. subfasciatus in bean grains treated with powders and sachets of different botanical species at $25 \pm 2{ }^{\circ} \mathrm{C}$, relative humidity of $70 \pm 10 \%$ and photoperiod of 12:12 (light:dark) h.

\begin{tabular}{|c|c|c|c|c|}
\hline \multirow[b]{2}{*}{ Botanical species } & \multicolumn{4}{|c|}{ Application forms } \\
\hline & Powder & \multicolumn{2}{|c|}{ Sachet Powder } & Sachet \\
\hline Control & $143.25 \pm 9.89 \mathrm{aA}$ & $115.75 \pm 7.72 \mathrm{aB}$ & $72.75 \pm 1.98 \mathrm{aA}$ & $75.77 \pm 3.35 \mathrm{aA}$ \\
\hline P. aduncum & $133.50 \pm 11.51 \mathrm{aA}$ & $114.38 \pm 3.76 \mathrm{aA}$ & $66.15 \pm 2.03 \mathrm{aA}$ & $49.65 \pm 1.28 \mathrm{~dB}$ \\
\hline A. indica & $112.63 \pm 5.06 \mathrm{bA}$ & $101.25 \pm 7.84 \mathrm{aA}$ & $65.61 \pm 3.36 \mathrm{aA}$ & $57.59 \pm 6.04 \mathrm{cA}$ \\
\hline P. tuberculatum & $105.50 \pm 5.43 \mathrm{bA}$ & $99.38 \pm 3.97 \mathrm{aA}$ & $64.49 \pm 2.01 \mathrm{aA}$ & $56.86 \pm 3.07 \mathrm{cA}$ \\
\hline T. pallida & $100.88 \pm 5.40 \mathrm{bA}$ & $111.00 \pm 8.19 \mathrm{aA}$ & $74.79 \pm 2.63 \mathrm{aA}$ & $67.37 \pm 2.90 \mathrm{bA}$ \\
\hline T. catigua & $99.38 \pm 16.40 \mathrm{bA}$ & $92.50 \pm 6.95 \mathrm{aA}$ & $71.88 \pm 6.36 \mathrm{aA}$ & $61.21 \pm 3.32 \mathrm{bB}$ \\
\hline P. glomerata & $95.25 \pm 11.53 \mathrm{bA}$ & $99.00 \pm 5.00 \mathrm{aA}$ & $73.54 \pm 2.65 \mathrm{aA}$ & $54.52 \pm 3.03 \mathrm{cB}$ \\
\hline R. graveolens & $65.50 \pm 10.57 \mathrm{cB}$ & $101.63 \pm 4.55 \mathrm{aA}$ & $0.11 \pm 0.11 \mathrm{cB}$ & $50.61 \pm 3.84 \mathrm{dA}$ \\
\hline \multirow[t]{2}{*}{ M. pulegium } & $49.25 \pm 4.37 \mathrm{cA}$ & $67.88 \pm 4.42 \mathrm{bA}$ & $22.79 \pm 3.36 \mathrm{bB}$ & $42.18 \pm 5.79 \mathrm{dA}$ \\
\hline & \multicolumn{2}{|c|}{ Number of eggs } & \multicolumn{2}{|c|}{ Eggs viability } \\
\hline Botanical species (S) & \multicolumn{2}{|c|}{$<0.001$} & \multicolumn{2}{|c|}{$<0.001$} \\
\hline Application form $(\mathrm{F})$ & \multicolumn{2}{|c|}{$>0.050$} & \multicolumn{2}{|c|}{$>0.050$} \\
\hline$E \times F$ & \multicolumn{2}{|c|}{$<0.001$} & \multicolumn{2}{|c|}{$<0.001$} \\
\hline
\end{tabular}

${ }^{1}$ Means followed by same lowercase letters in the column or uppercase in the row, did not significantly differ by SkottKnott test $(\mathrm{p} \geq 0.05)$.

Regarding the eggs' viability, the interaction was significant to some treatments. $R$. graveolens, which deterred $99,89 \%$ of the eggs to hatch at the same powder application form, differing from the other treatments. At this same form of application, M. pulegium also presented low egg viability $(22,79$ $\%)$, characterizing it as the second best treatment and also differing from the other treatments (Table 2). The increase of egg viability in $R$. graveolens and $M$. pulegium for the sachet form of application is probably associated with the absence of contact of the powders of these treatments to the eggs, similarly to the previous discussion in Table 1 . Differently to the obtained results at the current study, Pannuti, Marchi and Baldin (2012) did not verify negative effects over the eggs viability of Callosobruchus maculatus Fabr. (Coleoptera: Bruchidae) in bean grains variety caupi mixed with $R$. graveolens and
M. pulegium powders (p/p). Probably, the deleterious effects of the compounds' derivative from these botanical species varied according to the insect species.

Based on the oviposition preference index, all the botanical species in the powder form of application were classified as deterrents when compared to the control, with exception to $P$. aduncum (-3.84). For the sachet form of application, only $P$. aduncum (-0.09) and T. pallida (-2.41) did not reduce the oviposition preference of $Z$. subfasciatus and were classified as neutral. In a general way, it is possible to deduce that the presence of $R$. graveolens and $M$. pulegium derivatives, independently of the used application form, made the bean grains less favorable to oviposition of $Z$. subfasciatus compared to control (Figure 2). 


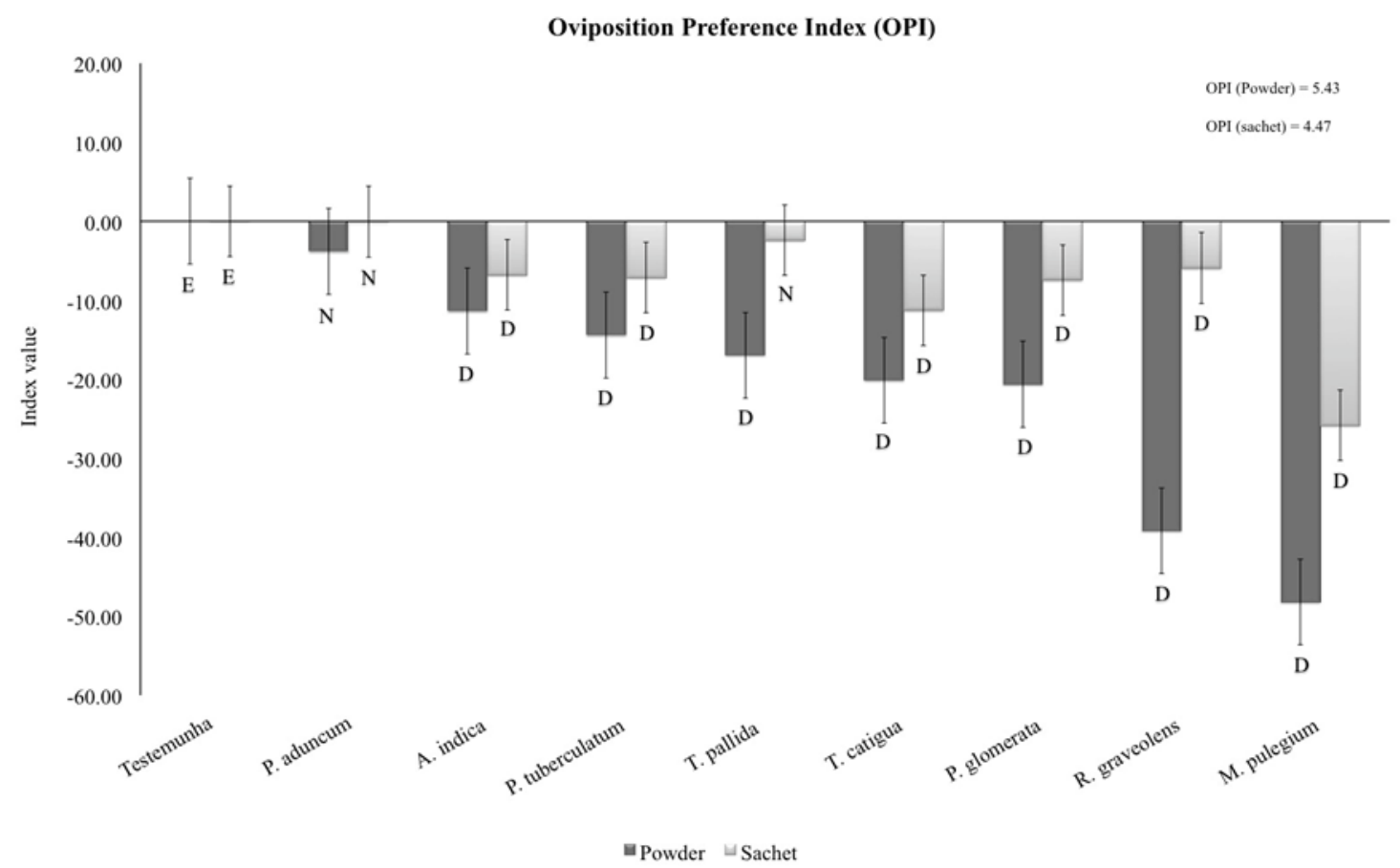

$\mathrm{N}=$ Neutral; $\mathrm{E}=$ Stimulant $\mathrm{R}=$ Repellent.

$\mathrm{OPI}=[(\mathrm{T}-\mathrm{P} / \mathrm{T}+\mathrm{P})] \times 100 . \mathrm{T}$ is the number of counted eggs in each treatment of treated bean grains and $\mathrm{P}$ is the total number of counted eggs in the control (without powder/sachet). The index varies from +100 (very stimulant) to -100 (total deterrent), whereas a value of zero value indicates neutrality.

Figure 2. Oviposition preferred index and the classification of the botanical species to Z. subfasciatus in treated bean grains with powder and sachet forms of application at $25 \pm 2{ }^{\circ} \mathrm{C}$, relative himudity of $70 \pm 10 \%$, and photoperiod of 12:12 (light:dark) h.

Regarding the adult emergence of $Z$. subfasciatus, the interaction was significant to the $P$. tuberculatum and $P$. aduncum treatments,

demonstrating less emergence in the sachet form (Table 3).

Tabela 3. 1 Mean followed by same lowercase letters in the column or uppercase in the row, did not significantly differ by Skott-Knott test ( $\mathrm{p} \geq 0.05) .2$ R. graveolens (powder) was not included in the statistical analysis once this treatment deterred all the eggs.

\begin{tabular}{|c|c|c|c|c|}
\hline \multirow[b]{3}{*}{ Botanical species } & \multicolumn{2}{|c|}{ Numeber of emerged adults ${ }^{1,2}$} & \multicolumn{2}{|c|}{ Development from egg to adult (days) ${ }^{1,}$} \\
\hline & \multicolumn{4}{|c|}{ Application form } \\
\hline & Powder & Sachet & Powder & Sachet \\
\hline Control & $91.52 \pm 4.88 \mathrm{aA}$ & $79.77 \pm 7.25 \mathrm{aA}$ & $34.21 \pm 0.19 \mathrm{bA}$ & $31.44 \pm 0.19 \mathrm{cB}$ \\
\hline P. tuberculatum & $82.23 \pm 8.67 \mathrm{aA}$ & $50.78 \pm 4.22 \mathrm{bB}$ & $34.30 \pm 0.28 \mathrm{bA}$ & $33.51 \pm 0.15 \mathrm{aB}$ \\
\hline T. pallida & $72.13 \pm 8.39 \mathrm{bA}$ & $63.26 \pm 4.84 \mathrm{aA}$ & $34.95 \pm 0.16 \mathrm{aA}$ & $32.29 \pm 0.29 \mathrm{bB}$ \\
\hline P. aduncum & $71.73 \pm 5.30 \mathrm{bA}$ & $49.27 \pm 2.64 \mathrm{bB}$ & $34.61 \pm 0.17 \mathrm{aA}$ & $34.04 \pm 0.27 \mathrm{aA}$ \\
\hline A. indica & $66.50 \pm 5.94 \mathrm{bA}$ & $49.88 \pm 4.95 \mathrm{bA}$ & $35.32 \pm 0.23 \mathrm{aA}$ & $32.62 \pm 0.32 \mathrm{bB}$ \\
\hline P. glomerata & $64.50 \pm 9.86 \mathrm{bA}$ & $47.13 \pm 3.24 \mathrm{bA}$ & $33.49 \pm 0.17 \mathrm{cA}$ & $33.52 \pm 0.12 \mathrm{aA}$ \\
\hline T. catigua & $58.74 \pm 10.85 \mathrm{bA}$ & $52.75 \pm 6.69 \mathrm{bA}$ & $34.99 \pm 0.15 \mathrm{aA}$ & $32.35 \pm 0.19 \mathrm{bB}$ \\
\hline M. pulegium & $10.74 \pm 1.74 \mathrm{cA}$ & $25.76 \pm 4.90 \mathrm{cA}$ & $35.40 \pm 0.08 \mathrm{aA}$ & $31.51 \pm 0.21 \mathrm{cB}$ \\
\hline \multirow[t]{3}{*}{$R$. graveolens } & ----- & $43.38 \pm 4.02$ & ----- & $33.10 \pm 0.32$ \\
\hline & \multicolumn{4}{|c|}{ P probability } \\
\hline & \multicolumn{2}{|c|}{ Number of emerged adults } & \multicolumn{2}{|c|}{ Development from egg to adult } \\
\hline Botanical species $(\mathrm{E})$ & \multicolumn{2}{|c|}{$<0.001$} & \multicolumn{2}{|c|}{$<0.001$} \\
\hline Application form $(\mathrm{F})$ & \multicolumn{2}{|c|}{$<0.001$} & \multicolumn{2}{|c|}{$<0.001$} \\
\hline $\mathrm{E} \times \mathrm{F}$ & \multicolumn{2}{|c|}{0.0321} & \multicolumn{2}{|c|}{$<0.001$} \\
\hline
\end{tabular}

${ }^{1}$ Mean followed by same lowercase letters in the column or uppercase in the row, did not significantly differ by Skott-Knott test $(\mathrm{p} \geq 0.05){ }^{2} R$. graveolens (powder) is not included the statistical analysis once this treatment deterred all the eggs.

R. graveolens did not present the same efficiency in the sachet form when compared to the powder application and allowed the emergence of adults close to the other treatments (Table 3). The need of contact from powder of this species with the grains has already been previously described (Table 2).

The species of the genus Mentha hold a vast 
variety of bioactive compounds such as menthol, carvone, linolool, pulegone, $\alpha$-pinene, and others, which can cause deleterious effects in the behavior and biology of several weevil species, including Sitophilus oryzae Linné, 1763 (Coleoptera: Curculionidae), Tribolium castaneum H. (Coleoptera: Tenebrionidae), and C. maculatus (KUMAR et al., 2011). Even though this genus encloses several species known by the bioactivity over inect-pest, this is the first description of the deleterious effect of $M$. pulegium over $Z$. subfasciatus reported in literature.

Regarding $P$. tuberculatum, T. pallida, $A$. indica, T. catigua, and $M$. pulegium, the use of powder mixed with the grains significantly extended the egg-adult development of $Z$. subfasciatus when compared to the sachet form. The species $M$. pulegium (35.40), A. indica (35.32), T. catigua (34.99), T. pallida (34.95) (powder form) and $P$. aduncum (powder and sachet forms) presented the best results with regards to the extension of egg-adult period of $Z$. subfasciatus (Table 3 ). Weevils including $Z$. subfasciatus, when under storage conditions, can reproduce rapidly and complete several cycles in a short period of time. There are several side effects caused by the volatiles over the weevil, including the alteration of the cycle once its extension allows the reduction of insect generations and inhibits its multiplication, and the damage caused by the increased number of inects in the grain mass.

The results of this study indicate that the application of botanical species in powder form mixed with bean grains is the most efficient control of $Z$. subfasciatus in relation to the sachet form. The application of powder of $A$. indica and $R$. graveolens mixed to the grains and $P$. aduncum in the sachet form can make the bean grains less susceptible to the insect colonization. Additionally, the application of treatments based on $A$. indica, $P$. tuberculatum, $T$. catigua, $P$. glomerata, $R$. graveolens, and $M$. pulegium, regardless the application form used, can make the bean grains less favorable to the oviposition of $Z$. subfasciatus. The species of $R$. graveolens and $M$. pulegium demonstrated to be highly efficent in the population reduction of $Z$. subfasciatus.

Although more studies are needed towards the isolation of bioactive substances as well as the definition of the concentration of these substances and application form, the results from this study demonstrated a high potential for the use of $R$. graveolens and M. pulegium as natural insecticides against $Z$. subfasciatus. Their use are associated to other strategies that could contribute to the reduction of synthetic insecticide application in grain storage bins.

\section{CONCLUSIONS}

The efficiency of the powder application form mixed to the bean grains was higher than the sachet form in the management and control of Zabrotes subfasciatus.

The adults were repelled by the bean grains that were treated with the powders of $A$. indica and $R$. graveolens as well as $P$. aduncum in the sachet form.

The oviposition of $Z$. subfasciatus was inhibited by the bean grains that were treated with powder of $A$. indica, $P$. tuberculatum, T. catigua, $P$. glomerata, $R$. graveolens, and $M$. pulegium, regardless of the application form used.

The egg viability and the insect emergence was reduced by the powders of $R$. graveolens and $M$. pulegium; therefore, they exhibit great potential as alternatives for controlling $Z$. subfasciatus in stored beans.

\section{ACKNOWLEDGEMENTS}

The authors thank the FAPESP and CNPq for the financial support. We also thank Dr. Massuo Jorge Kato for providing the derivatives of Piper $\mathrm{sp}$

\section{REFERENCES}

BALDIN, E. L. L. et al. Resistência de genótipos de feijoeiro Phaseolus vulgaris (L.) a Zabrotes subfasciatus (Boh., 1833) (Coleoptera: Bruchidae). Boletin Sanidad Vegetal Plagas, Santiago, v. 33, n. 3, p. 369-375, 2007.

BALDIN, E. L. L. et al. Efeitos de pós vegetais sobre Zabrotes subfasciatus Bohemann (Coleoptera: Bruchidae) em grãos de feijão armazenado. Boletin de Sanidad Vegetal de Plagas, Santiago, v. 34, n. 2, p. 177-185, 2008.

BALDIN, E. L. L. et al. Use of vegetable powders in the control of Acanthoscelides obtectus Say (Coleoptera: Bruchidae) in stored bean grains. BioAssay, Piracicaba, v. 4, n. 2, p. 1-6, 2009.

BARBOZA, J. et al. Phagodeterrence by a crude extract of common rue (Ruta chalepensis, Rutaceae) and its partitions on Hypsipyla grandella (Lepidoptera: Pyralidae) larvae. Revista Biologia Tropical, San Jose, v. 58, n. 1, p. 1-14, 2010.

BROUGHTON, W. J. et al. Beans (Phaseolus spp.) -model food legumes. Plant Soil, Crawley, v. 252, n. 1, p. 55-128, 2003.

CARDONA, C. et al. Antibiosis effects of wild dry bean accessions on the Mexican bean weevil and the 
bean weevil (Coleoptera: Bruchidae). Journal of Economic Entomology, Annapolis, v. 82, n. 1, p. 310-315, 1989.

CASTRO, M. J. P. et al. Characterization of cowpea genotype resistance to Callosobruchus maculatus. Pesquisa Agropecuária Brasileira, Brasília, v. 48, n. 9, p. 1201-1209, 2013.

CORTÉS, A. J. et al. Nucleotide diversity patterns at the drought-related DREB2 encoding genes in wild and cultivated common bean (Phaseolus vulgaris L.). Theoretical and Applied Genetics, Stuttgart, v. 125, n. 5, p. 1069-10852012.

COSTA, J. T. et al. Effects of different formulations of neem oil-based products on control Zabrotes subfasciatus (Boheman, 1833) (Coleoptera: Bruchidae) on Beans. Journal of Stored Products Research, Manhattan, v. 56, n. 1, p. 49-53, 2014.

GUARRERA, P. M. Traditional antihelmintic, antiparasitic and repellent uses of plants in Central Italy, Journal of Ethnopharmacology, Leiden, v. 68, n. 1-3, p. 183-192, 1999.

GUSMÃO, N. M. S. et al. Contact and fumigant toxicity and repellency of Eucalyptus citriodora Hook., Eucalyptus staigeriana F., Cymbopogon winterianus Jowitt and Foeniculum vulgare Mill. essential oils in the management of Callosobruchus maculatus (FABR.) (Coleoptera: Chrysomelidae, Bruchinae). Journal of Stored Products Research, Manhattan, v. 54, n. 1, p. 41-47, 2013.

HILLOCKS, R. J. et al. Phaseolus bean improvement in Tanzania, 1959-2005. Euphytica, Wageningen, v. 150, n. 1, p. 215-231, 2006.

ISMAN, M. B. Botanical insecticides, deterrents, and repellents in modern agriculture and an increasingly regulated world. Annual Review Entomology, Palo Alto, v. 51, n. 1, p. 45-66, 2006.

KEMABONTA, K. A.; ODEBIYI, J. A. Susceptibility of the life stages of Callosobruchus maculatus Fab. (Coleoptera: Bruchidae) to diflubenzuron in cowpea seeds. Journal of Plant Diseases and Protection, Stuttgart, v. 112, n. 2, p. 193-199, 2005.

Kumar, P. et al. Insecticidal properties of Mentha species: a review. Industrial Crops and Products, Amsterdam, v. 34, n. 1, p. 802-817, 2011.

LIN, H.; KOGAN, M.; FISCHER, D. Induced resistance in soybean to the mexican bean beetle (Coleoptera; Coccinellidae): Comparisons of inducing factors. Environmental Entomology, Annapolis, v. 19, n. 6, p. 1852-1857, 1990.
MAGALHÃES, S. T. V. et al. Leaf alkaloids, phenolics, and coffee resistance to the leaf miner Leucoptera coffeella (Lepidoptera: Lyonetiidae). Journal of Economic Entomology, Annapolis, v. 103, n. 4, p. 1438-1443, 2010.

MAZZONETTO, F.; VENDRAMIM, J. D. Efeito de pós de origem vegetal sobre Acanthoscelides obtectus (Say) (Coleoptera: Bruchidae) em feijão armazenado. Neotropical Entomology, Londrina, v. 32, n. 1, p. 145-149, 2003.

MIRESMAILLI, S.; BRADBURY, R.; ISMAN, M. B. Comparative toxicity of Rosmarinus officinalis $\mathrm{L}$. essential oil and blends of its major constituents against Tetranychus urticae Koch (Acari: Tetranychidae) on two different host plants. Pest Management Science, Oxford, v. 62, n. 4, p. 366371, 2006.

MOHAN, S.; PRETHEEP-KUMAR, P.; BALASUBRAMANIAN, P. Insecticide resistance - stored -product insects. Dusseldorf, LAP Lambert Academic Publishing, 2010.

MOREIRA, M. D. et al. Plant compounds insecticide activity against Coleoptera pests of stored products. Pesquisa Agropecuária Brasileira, Brasília, v. 42, n. 7, p. 909-915, 2007.

MORGAN, E. D. Azadirachtin, a scientific gold mine. Bioorganic and Medicinal Chemistry, Philadelphia, v. 17, n. 12, p. 4096-4105, 2009.

OJWANG' P. P. O. et al. Breeding options for improving common bean for resistance against bean fly (Ophiomyia spp.): a review of research in eastern and southern Africa. Euphytica, Wageningen, v. 179, n. 3, p. 363-371, 2011.

OLIVA, A. et al. Natural fungicides from Ruta graveolens leaves including a new quinolon alkaloid. Journal of Agricultural and Food Chemistry, Davis, v. 51, n. 4, p. 890-896, 2003.

PANNUTI, L. E. R.; MARCHI, L. S.; BALDIN, E. L. L. Use of vegetable powders as alternative to control of Callosobruchus maculatus. Boletín de Sanidad Vegetal Plagas, Santiago, v. 38, n. 1, p. 3340, 2012.

PAUL, U. V. et al. Effectiveness of products from four locally grown plants for the management of Acanthoscelides obtectus (Say) and Zabrotes subfasciatus (Boheman) (both Coleoptera: Bruchidae) in stored beans under laboratory and farm conditions in Northern Tanzania. Journal of Stored Products Research, Manhattan, v. 45, n. 2, p. 97107, 2009 
ROJHT, H.; KOSIR, I. J.; TRDAN, S. Chemical analysis of three herbal extracts and observation of their activity against adults of Acanthoscelides obtectus and Leptinotarsa decemlineata using a video tracking system. Journal of Plant Diseases and Protection, Stuttgart, v. 119, n. 2, p. 59-67, 2012.

SCOTT, I. M. et al. A review of Piper ssp. (Piperaceae) phytochemistry, insecticidal activity and mode of action. Phytochemistry Reviews, New Orleans, v. 7, n. 1, p. 65-75, 2008.

SINGH, S. R.; VAN EMDEN, F. H. Insect pests of grain legumes. Annual Review Entomology, Annapolis, v. 24, n. 1, p. 255-278, 1979.

SISVAR - Sistema de análise de variância. Versão 5.3. Lavras, Minas Gerais: UFLA, 2010.

WEAVER, D. K. et al. Insecticidal activity of floral, foliar, and root extracts of Tagetes minuta (Asterales: Asteraceae) against adult Mexican bean weevil (Coleoptera: Bruchidae). Journal of Economic Entomology, Annapolis, v. 87, n. 6, p. 1718-1725, 1994.

WINER, B. J. et al. Statistical principles in experimental design, 3 ed. Nova Iorque: McGrawHill, 1991, 1057 p.

WONG-CORRAL, F. J.; CASTAÑÉ, C.; RIUDAVETS, J. Lethal effects of CO2-modified atmospheres for the control of three Bruchidae species. Journal of Stored Products Research, Manhattan, v. 55, n. 1, p. 62-67, 2013. 